\title{
PENGARUH PIJAT OKSITOSIN TERHADAP PRODUKSI ASI PADA IBU NIFAS
}

\author{
Yusari Asih* \\ *Dosen Jurusan Kebidanan Poltekkes Tanjungkarang \\ e-mail: yusariasih@gmail.com
}

\begin{abstract}
ASI tidak keluar adalah kondisi tidak diproduksinya ASI atau sedikitnya produksi ASI. Hal ini disebabkan pengaruh hormon oksitosin yang kurang bekerja sebab kurangnya rangsangan isapan bayi yang mengaktifkan kerja hormon oksitosin. Pijat oksitosin merupakan salah satu solusi untuk mengatasi ketidaklancaran produksi ASI. Tujuan penelitian ini untuk mengidentifikasi perbedaan produksi ASI pada ibu nifas yang diberi perlakuan pijat oksitosin dan tanpa perlakuan di BPM Lia Maria Kecamatan Sukarame Bandar Lampung tahun 2017. Metode penelitian yang digunakan dalam penelitian ini adalah eksperimental dengan desain rancangan posttest dengan kelompok kontrol. Populasi pada penelitian ini adalah ibu nifas 3 jam postpartum di BPM Lia Maria berjumlah 80 orang. Sampel dalam penelitian ini diambil melalui cara purposive sampling. Sampel berjumlah 32 orang yang terdiri dari 16 orang sebagai responden yang di intervensi dan 16 orang sebagai variabel kontrol. Instrumen penelitian yang digunakan berupa lembar observasi untuk mengamati produksi ASI pada hari ke 6 dan timbangan. Hasil Uji statistik menggunakan chi-square $\left(\mathrm{x}^{2}\right)$ diperoleh $\mathrm{p}$-value $=0,037$ ( $\mathrm{p}$-value $\leq 0,05$ ) yang berarti ada pengaruh signifikan antara pijat oksitosin terhadap produksi ASI pada ibu post partum di BPM Lia Maria Sukarame Bandar Lampung Tahun 2017. Diharapkan hasil penelitian ini dapat meningkatkan kualitas pelayanan bagi tenaga kesehatan terutama bidan sebagai pelaksana sehingga dapat meningkatkan pengetahuan ibu akan pijat oksitosin dan dapat memotivasi ibu dan keluarga untuk melakukan pijat oksitosin dan memberikan bimbingan serta penyuluhan kepada ibu nifas tentang manfaat pijat oksitosin.
\end{abstract}

Kata kunci: Pijat oksitosin, Produksi ASI

\section{LATAR BELAKANG}

Di Indonesia hampir 9 dari $10 \mathrm{ibu}$ pernah memberikan ASI, namun penelitian IDAI (Yohmi dkk, 2015) menemukan hanya 49,8\% yang memberikan ASI secara eksklusif selama 6 bulan sesuai rekomendasi WHO. Rendahnya cakupan pemberian ASI ekslusif ini dapat berdampak pada kualitas hidup generasi penerus bangsa dan juga pada perekonomian nasional. (IDAI, 2016)

Dalam Riskesdas 2013 yang menjadi salah satu indikator yang dapat digunakan untuk PHBS sesuai dengan kriteria PHBS yang ditetapkan oleh Pusat Promkes pada tahun 2011, yaitu memberi ASI eksklusif. Proses mulai menyusui terbanyak terjadi pada 1-6 jam setelah kelahiran $(35,2 \%)$ dan kurang dari 1 jam (inisiasi menyusui dini) sebesar $34,5 \%$. Sedangkan proses mulai menyusui terendah terjadi pada 7-23 jam setelah kelahiran yaitu sebesar 3,7\% (Kemenkes RI, 2015)
Hubungan antara perkembangan bayi dan pemberian ASI telah banyak diteliti. Meta-analisis yang dilakukan Anderson et al. (1999) menyimpulkan bahwa bayi yang diberikan ASI memiliki tingkat perkembangan kognitif yang lebih tinggi dibandingkan bayi yang diberilan susu formula. Salah satu penjelasan dari hasil penelitian tersebut adalah $60 \%$ dari otak bayi tersusun dari lemak, terutama DHA dan asam arachidonat (AA), dan ASI mengandung asam lemak tak jenuh rantai panjang (LCPUFAs) seperti DHA dan AA yang merupakan zat gizi ideal untuk pertumbuhan otak bayi yang belum matang (Fikawati dkk, 2015)

Kekurangan gizi yang terjadi pada awal kehidupan dapat mengakibatkan terjadinya growth faltering (gagal tumbuh) sehingga bayi akan tumbuh menjadi anak yang lebih pendek dari normal. Selain itu, kekurangan gizi juga dapat berpengaruh terhadap perkembangan kognitif, morbiditas dan mortalitas bayi. Gizi yang baik akan mempercepat pemulihan dan 
mengurangi intensitas (kegawatan) penyakit infeksi pada bayi. Kejadian infeksi pada bayi tidak dapat disepelekan, mengingat infeksi merupakan penyebab utama kematian bayi di negara berkembang( Fikawati dkk, 2015)

Kasus kematian bayi di Kota Bandar Lampung selama tahun 2009-2014 fluktuatif. Kematian bayi tersebut tahun 2009 menjadi 127 kasus, dalam kurun waktu 2 tahun berikutnya, AKB di Kota Bandar Lampung dalam dua tahun terakhir meningkat. Tahun 2010 tercatat AKB menjadi 195 kasus. Tahun 2011 menurun menjadi 167 kasus, namun pada tahun 2012 ini meningkat kembali menjadi 204 kasus, tahun 2013 menurun 168 kasus dan tahun 2014 meningkat menjadi 169 kasus. Dari 169 kasus kematian bayi, bila dilihat berdasarkan kelompok umur maka kematian neonatal (0-28 hari) menyumbang angka tertinggi dari kematian bayi yang ada, kematian neonatal tahun ini sebanyak 135 kasus dan kematian bayi 34 kasus. Beberapa penelitian diperoleh bahwa salah satu faktor-faktor yang turut mempengaruhi kematian bayi adalah masih rendahnya pemberian air susu ibu (ASI) eksklusif. (Profil Kesehatan Lampung 2014, hal. 82)

Kasus kematian bayi tahun 2014 sebanyak 168 kasus tersebar di 30 puskesmas, dengan kasus tertinggi berada di Puskesmas Kemiling 14 kasus dan yang tidak memiliki kasus terdapat di Puskesmas Permata Sukarame, Korpri, dan Way Laga. Kematian bayi ini meliputi kematian neonatal 135 kasus dan kematian bayi 34 kasus. Data jumlah kelahiran hidup pada tahun 2014 sebanyak 20.427 bayi. Melihat target nasional sebanyak 23 per $1000 \mathrm{KH}$, maka kematian bayi yang tercatat di Bandar Lampung 169 per $20.427 \mathrm{KH}(0,0082)$ masih jauh di bawah angka nasional $(0,023)$. Walaupun demikian masih diperlukan peningkatan pelayanan kesehatan ibu dan bayi guna lebih menekan angka kematian bayi melalui berbagai kegiatan baik promotif, preventif maupun kuratif, dan meningkatkan peran serta masyarakat serta lintas sektor tentunya.
ASI tidak keluar adalah kondisi tidak diproduksinya ASI atau sedikitnya produksi ASI. Hal ini disebabkan pengaruh hormon oksitosin yang kurang bekerja sebab kurangnya rangsangan isapan bayi yang mengaktifkan kerja hormon oksitosin.( Fikawati dkk, 2015: 83) Hormon oksitosin bekerja merangsang otot polos untuk meremas ASI yang ada pada alveoli, lobus serta duktus yang berisi ASI yang dikeluarkan melalui putting susu. (Walyani dan Purwoastuti, 2015)

Menurut Fikawati, dkk (2015) menyebutkan bahwa salah satu tindakan yang perlu dilakukan untuk memaksimalkan kualitas dan kuantitas ASI, yaitu pemijatan punggung. Pemijatan punggung ini berguna untuk merangsang pengeluaran hormon oksitosin menjadi lebih optimal dan pengeluaran ASI menjadi lancar. Menurut Lowdermik, Perry \& Bobak (2000), pijat oksitosin merupakan salah satu solusi untuk mengatasi ketidaklancaran produksi ASI. Pijat Oksitosin adalah pemijatan pada sepanjang tulang belakang (vertebrae) sampai tulang costae kelima-keenam dan merupakan usaha untuk merangsang hormon prolaktin dan oksitosin setelah melahirkan.

Dari hasil pre survey yang dilakukan oleh peneliti di BPM Lia Maria Kec. Sukarame Bandar Lampung belum melakukan pijat oksitosin pada saat memberikan asuhan kebidanan pada ibu post partum baik untuk merangsang keluarnya ASI maupun untuk involusi uterus dan BPM Lia Maria yang merupakan BPM yang berada di wilayah kerja Puskesmas Permata Sukarame yang tidak terdapat jumlah kasus kematian bayi.

\section{METODE}

Penelitian ini dilakukan bertujuan untuk mengetahui pengaruh pijat oksitosin terhadap produksi ASI pada ibu nifas di BPM Lia Maria. Metode penelitian yang digunakan dalam penelitian ini adalah eksperimental dengan desain rancangan posttest dengan kelompok kontrol. 
Populasi pada penelitian ini adalah ibu nifas 3 jam postpartum di BPM Lia Maria berjumlah 80 orang. Sampel dalam penelitian ini diambil melalui cara purposive sampling. Sampel berjumlah 32 orang yang terdiri dari 16 orang sebagai responden yang di intervensi dan 16 orang sebagai variabel kontrol.

Data penelitian dikumpulkan dengan melakukan pemijatan oksitosin setelah 3 jam postpartum dan selama 5 hari tiap pagi dan sore hari selanjutnya dilakukan observasi pada hari ke-6. Data yang terkumpul selanjutnya diproses dan dianalisis secara univariat dan bivariat menggunakan uji chi-square dengan bantuan perangkat lunak komputer.

\section{HASIL}

\section{Analisis Univariat}

Tabel 1: Distribusi Frekuensi Responden Berdasarkan Usia

\begin{tabular}{|c|c|c|}
\hline Usia & $\mathrm{f}$ & $\%$ \\
\hline$<20$ & 1 & 3,1 \\
\hline $20-30$ & 21 & 65,6 \\
\hline$>30$ & 10 & 31,2 \\
\hline Jumlah & 32 & 100 \\
\hline
\end{tabular}

Berdasarkan tabel 1 dapat diketahui dari 32 responden sebagian besar mempunyai usia 20-30 tahun yaitu 21 responden $(65,6 \%)$.

Tabel 2: Distribusi Frekuensi Responden Berdasarkan Pendidikan

\begin{tabular}{|c|c|c|}
\hline Pendidikan & $f$ & $\%$ \\
\hline SD & 2 & 6,2 \\
\hline SMP & 11 & 34,4 \\
\hline SMA & 14 & 43,8 \\
\hline PT & 5 & 15,6 \\
\hline Jumlah & 32 & 100 \\
\hline
\end{tabular}

Berdasarkan tabel 2 dapat diketahui dari 32 responden sebagian besar mempunyai pendidikan SMA yaitu 14 responden $(43,8 \%)$.
Tabel 3: Distribusi Frekuensi Responden Berdasarkan Pekerjaan

\begin{tabular}{lcc}
\hline \multicolumn{1}{c}{ Pekerjaan } & $\mathrm{f}$ & $\%$ \\
\hline Bekerja & 2 & 6,2 \\
\hline Tidak bekerja & 30 & 93,8 \\
\hline Jumlah & 32 & 100 \\
\hline
\end{tabular}

Berdasarkan tabel 3 diketahui dari 32 responden sebagian besar responden tidak bekerja yaitu 30 responden $(93,8 \%)$.

Tabel 4: Distribusi Frekuensi Responden Berdasarkan Paritas

\begin{tabular}{lll}
\hline \multicolumn{1}{c}{ Paritas } & f & $\%$ \\
\hline Primigravida & 9 & 28,1 \\
Multigravida & 23 & 71,9 \\
\hline Jumlah & 32 & 100 \\
\hline
\end{tabular}

Berdasarkan tabel 4 diketahui dari 32 responden sebagian besar responden multigravida yaitu 23 responden $(71,9 \%)$.

\section{Analisis Bivariat}

Tabel 5: Distribusi Pengaruh Pijat Oksitosin terhadap Produksi ASI pada Ibu Post Partum

\begin{tabular}{|c|c|c|c|c|c|c|}
\hline \multirow{3}{*}{$\begin{array}{c}\text { Pijat } \\
\text { Oksitosin }\end{array}$} & \multicolumn{4}{|c|}{ Produksi ASI } & \multirow{2}{*}{$\begin{array}{c}\mathrm{p} \\
\text { value }\end{array}$} & \multirow{2}{*}{ OR } \\
\hline & \multicolumn{2}{|c|}{ Cukup } & \multicolumn{2}{|c|}{ Kurang } & & \\
\hline & $\mathrm{f}$ & $\%$ & $\mathrm{f}$ & $\%$ & & \\
\hline Pijat & 15 & 93,75 & 1 & 6,25 & & 11,667 \\
\hline Tidak Pijat & 9 & 56,2 & 7 & 43,8 & 0,037 & $(1,227-$ \\
\hline$\overline{\text { Total }}$ & 24 & 75 & 8 & 25 & & \\
\hline
\end{tabular}

Berdasarkan analisis pengaruh pijat oksitosin terhadap produksi ASI diketahui bahwa dari 16 responden yang melakukan pijat oksitosin terdapat 15 orang mengalami produksi ASI yang cukup, sedangkan dari 16 responden yang tidak melakukan pijat oksitosin terdapat 9 orang mengalami produksi ASI yang cukup. Hasil Uji statistik menggunakan chi-square $\left(\mathrm{x}^{2}\right)$ diperoleh $\mathrm{p}$-value $=0,037$ ( $\mathrm{p}$-value $\leq 0,05)$ yang berarti ada pengaruh signifikan antara pijat oksitosin terhadap produksi ASI pada ibu post partum di BPM Lia Maria Sukarame Bandar Lampung Tahun 2017. Dari hasil analisis 
diperoleh pula nilai OR $=11,667(1,227$ 110,953), yang artinya ibu post partum yang melaksanakan pijat oksitosin mempunyai peluang 11,667 kali mengalami produksi ASI cukup dibandingkan dengann ibu yang tidak melakukan pijat oksitosin.

\section{PEMBAHASAN}

\section{Produksi ASI pada Ibu Nifas yang Melakukan Pijat Oksitosin}

Berdasarkan hasil penelitian diketahui bahwa dari 16 responden yang melakukan pijat oksitosin terdapat 15 orang memiliki produksi ASI yang cukup dan 1 responden yang memiliki produksi ASI yang kurang.

Hal ini sejalan dengan teori yang ada bahwa pijat stimulasi oksitosin untuk ibu menyusui berfungsi untuk merangsang hormon oksitosin agar dapat memperlancar ASI dan meningkatkan kenyamanan ibu.

Pijat oksitosin merupakan salah satu solusi untuk mengatasi ketidaklancaran produksi ASI. Pijat oksitosin adalah pemijatan pada sepanjang tulang belakang (vertebrae) sampai tulang costae kelimakeenam dan merupakan usaha untuk merangsang hormon prolaktin dan oksitosin setelah melahirkan. (Rahayu, 2016) Pijat ini dilakukan untuk merangsang refleks oksitosin atau refleks pengeluaran ASI. Ibu yang menerima pijat oksitosin akan merasa lebih rileks. (Monika, F.B. Monika, 2014).

Hasil penelitian yang dilakukan oleh Emy Suryani dan Kh Endah Widhi Astuti di BPM wilayah kabupaten Klaten didapatkan Hasil Analisa bivariat menunjukan adanya perbedaan rata rata berat badan bayi dengan $p$ value : 0.001 ,ada perbedaan frekuensi BAK yang bermakna dengan $p$ value $=0,001$ dan ada perbedaan frekuensi menyusu yang bermakna dengan $p$ value $=0,001$ serta ada perbedaan lama tidur yang bermakna dengan $p$ value $=0,001$. Dapat disimpulkan bahwa ada pengaruh pijat oksitosin terhadap produksi ASI dengan indikasi berat badan bayi, frekuensi bayi menyusu, frekuensi bayi BAK dan lama bayi tidur setelah menyusu.

Menurut analisa peneliti kecukupan produksi ASI pada ibu nifas di BPM Lia Maria Kecamatan Sukarame Bandar Lampung adalah baik. Pijat oksitosin yang dilakukan pada ibu nifas dapat membuat rileks dan nyaman, sehingga dapat mengurangi rasa lelah setelah melahirkan terutama pijat yang dilakukan setelah 3 jam postpartum. Ibu nifas yang dilakukan pijat oksitosin mengatakan bahwa selama dilakukannya pijat oksitosin ibu merasa nyaman dan rileks sehingga selama pemijatan ibu merasakan adanya aliran ASI yang menetes keluar.

Pijat oksitosin juga mudah dilakukan dengan gerakan yang tidak terlalu banyak sehingga dapat diingat oleh keluarga untuk dilakukan dan tak membutuhkan waktu yang lama. Dukungan dari suami dan keluarga juga berperan penting dalam menyusui. Salah satu wujud dukungan tersebut dapat dilihat dari suami dan keluarga menyetujui untuk melakukan pijat oksitosin sehingga ibu dapat termotivasi untuk menyusui bayinya serta adanya anggota keluarga yang bersedia membantu melakukan pekerjaan rumah yang biasa dilakukan ibu.

\section{Produksi ASI pada Ibu Nifas yang Tidak Melakukan Pijat Oksitosin}

Berdasarkan hasil penelitian diketahui bahwa dari 16 responden yang tidak melakukan pijat oksitosin terdapat 9 orang memiliki produksi ASI yang cukup dan 7 orang memiliki produksi ASI yang kurang.

Beberapa faktor yang diidentifikasi dapat mempengaruhi laktasi di antaranya adalah Faktor Biologis (Nutrisi, kondisi payudara, sistem endokrin, paritas, umur kehamilan, kebiasaan, istirahat), faktor psikologis, faktor sosial (sosio-emosional, sosio-ekonomi, tingkat pendidikan, faktor lainnya (perawatan payudara, pijat oksitosin, teknik marmet)

Hasil penelitian yang dilakukan Siti Nur Endah dan Imas Masdinarsah di Ruang Kebidanan Rumah Sakit Muhammadiyah Bandung Tahun 2011 
yaitu, waktu pengeluaran kolostrum kelompok perlakuan rata - rata 5,8 jam, sedangkan lama waktu kelompok kontrol adalah rata - rata 5,89 jam . Jumlah kolostrum yang dikeluarkan kelompok perlakuan rata - rata 5,333 cc sedangkan kelompok kontrol adalah rata - rata 0,0289 cc . Pijat oksitosin berpengaruh terhadap jumlah produksi kolostrum dengan P-value 0,009, dan pijat oksitosin tidak berpengaruh terhadap lama waktu pengeluaran kolostrum ibu post partum dengan P-value 0,939.

Menurut analisa peneliti kecukupan produksi ASI baik karena pada umumnya produksi ASI yang tidak melakukan pijat oksitosin cukup karena sebagian besar paritas responden adalah multipara sehingga kehamilan atau persalinan yang ke-2 memiliki kecenderungan lebih baik daripada yang pertama dalam hal laktogenesis dan galaktopoesis serta memiliki pengalaman dalam menyusui. Selain itu, ibu nifas yang menjadi responden tidak memiliki pantangan dalam makanan sehingga pola nutrisi baik protein dari ikan, kacang-kacangan yang dapat meningkatkan produksi ASI dapat terpenuhi. Mayoritas pekerjaan ibu adalah ibu rumah tangga sehingga saat siang hari ibu memiliki waktu untuk beristirahat. Dimana ibu menyusui sangat memerlukan tidur yang cukup dan efektif agar metabolisme dalam tubuhnya berjalan lancar.

\section{Pengaruh Pijat Oksitosin terhadap produksi ASI pada Ibu Nifas}

Berdasarkan analisis pengaruh pijat oksitosin terhadap kecukupan produksi ASI pada ibu nifas diketahui bahwa dari 16 responden yang melakukan pijat oksitosin terdapat 15 orang yang memiliki produksi ASI cukup, sedangkan dari 15 responden yang tidak melakukan pijat oksitosin terdapat 9 orang memiliki produksi ASI cukup.

Hasil Uji statistik menggunakan Chi Square $\left(x^{2}\right)$ diperoleh $\mathrm{p}$-value $=0,037(\mathrm{p}$ value $\leq 0,05$ ) yang berarti bahwa ada pengaruh signifikan antara pijat oksitosin terhadap produksi ASI di BPM Lia Maria
Sukarame Bandar Lampung Tahun 2017. Dari hasil analisis diperoleh pula nilai $\mathrm{OR}=$ OR $=11,667(1,227-110,953)$ yang artinya ibu post partum yang melakukan pijat oksitosin mempunyai peluang 11,667 kali memiliki peluang produksi ASI yang cukup dibandingkan dengan ibu yang tidak melakukan pijat oksitosin.

Produksi ASI sangat dipengaruhi oleh kondisi psikologis ibu menyusui. Saat ibu menyusui merasa nyaman dan rileks pengeluaran oksitosin dapat berlangsung dengan baik. Terdapat titik-titik yang dapat memperlancar ASI di antaranya, tiga titik di payudara yakni titik di atas puting, titik tepat pada puting dan titik dibawah puting, serta titik di punggung yang segaris dengan payudara. Pijat stimulasi oksitosin untuk ibu menyusui berfungsi untuk merangsang hormon oksitosin agar dapat memperlancar ASI dan meningkatkan kenyamanan ibu. Pijatan di bagian punggung ibu yang membuat ibu rileks juga dapat merangsang pengeluaran oksitosin.

Hormon oksitosin merangsang kontraksi lapisan miometrium uteri dalam proses persalinan. Hormon ini juga menghasilkan pengeluaran air susu melalui pengadaan kontraksi sel-sel mioepitel di kelenjar payudara sebagai respons terhadap pengisapan putting susu yang dilakukan si bayi, yang kemudian terjadilah refleks neurogenik (aliran listrik saraf) yang dihantarkan ke hipotalamus melalui serabut-serabut saraf di medula spinalis (daerah tulang belakang) (Hendrik $\mathrm{H}$., 2006)

Menurut Hockenberry (2002) menuliskan bahwa pijat oksitosin lebih efektif diberikan sebanyak dua kali dalam sehari yaitu pagi dan sore. Hal ini juga didukung oleh Biancuzzo (2003) bahwa pijat oksitosin dilakukan dua kali dalam sehari dapat memperngaruhi produksi ASI ibu postpartum.

Pijat oksitosin adalah suatu tindakan pemijatan tulang belakang mulai dari nervus ke 5 - 6 sampai scapula yang akan mempercepat kerja saraf parasimpatis untuk menyampaikan perintah ke otak bagian belakang sehingga oksitosin keluar (Suherni, 2008 Suradi, 2006; Hamranani 
2010) ( Dalam Fakultas Ilmu Keperawatan Universitas Padjadjaran, Leli Khairani dkk, 2012)

Hasil penelitian yang dilakukan Leli Khairani, Maria Komariah, dan Wiwi Mardiah mengenai pengaruh pijat oksitosin terhadap involusi uterus pada ibu post partum di ruang post partum kelas III RSHS Bandung yaitu teridentifikasi pengaruh oksitosin terhadap involusi uterus pada ibu post partum di Ruang Post Partum Kelas III RSHS Bandung, melalui uji statistik Chi-square dengan nilai $\mathrm{p}<$ 0.05 .

Berdasarkan teori dan hasil penelitian di atas menurut peneliti adanya pengaruh pijat oksitosin terhadap produksi ASI di BPM Lia Maria Kecamatan Sukarame Bandar Lampung Tahun 2017 karena dengan melakukan pijat oksitosin dapat merangsang hormon oksitosin yang berfungsi dalam pengeluaran ASI. Dilihat dari segi pekerjaan, sebagian besar responden tidak bekerja, seharusnya memungkinkan untuk melaksanakan pijat oksitosin baik oleh suami di pagi dan sore hari ataupun dilakukan oleh keluarga.

\section{KESIMPULAN}

Berdasarkan hasil analisis data dan pembahasan penelitian dapat disimpulkan ada pengaruh pijat oksitosin terhadap produksi ASI pada ibu nifas di BPM Lia Maria Kecamatan Sukarame Tahun 2017 yaitu $93,8 \%$ ibu nifas yang melakukan pijat oksitosin sebagian besar memiliki produksi ASI yang cukup, 56,2\% ibu nifas yang tidak melakukan pijat oksitosin terdapat 9 orang yang memiliki produksi ASI yang cukup.

Hasil analisis statistik lebih lanjut menyimpulkan bahwa ada pengaruh yang signifikan antara pijat oksitosin terhadap produksi ASI pada ibu nifas dengan pvalue 0,037 .

Berdasarkan kesimpulan tersebut penulis menyarankan kepada BPM Lia Maria untuk melakukan pijat oksitosin setelah 3 jam postpartum dan mengajarkan ibu nifas cara melakukan pijat oksitosin, melakukan penyuluhan mengenai pijat oksitosin di kelas ibu dan dapat memotivasi ibu dan keluarga untuk melakukan pijat oksitosin selama masa nifas, dan menyediakan leaflet atau brosur mengenai pijat oksitosin sehingga dapat meningkatkan pengetahuan ibu nifas akan pijat oksitosin.

\section{DAFTAR PUSTAKA}

Endah, Siti Nur dan Imas Masdinarsah. 2011. Pengaruh Pijat Oksitosin terhadap Pengeluaran Kolostrum pada Ibu Post Partum di Ruang Kebidanan di Rumah Sakit Muhammadiyah Bandung Tahun 2011. Stikes Jendral A. Yani Cimahi

F.B. Monika. 2014. Buku Pintar ASI dan Menyusui. Jakarta: Noura Books

Fikawati, Sandra; dkk. 2015. Gizi Ibu dan Bayi. Jakarta: PT Rajagrafindo Persada

Hendrik, H. 2006. Problema Haid. Solo: PT. Tiga Serangkai Pustaka Mandiri.

Kemenkes RI. 2014. Profil Kesehatan Indonesia 2014. BandarLampung: Dinas Kesehatan Kota Bandar Lampung

Khairani, Maria dkk. 2012. Pengaruh Pijat Oksitosin Terhadap Involusi Uterus pada Ibu Post Partum Di Ruang Post Partum Kelas III RSHS Bandung. Fakultas Ilmu Keperawatan Universitas Padjadjaran

Rahayu, Anik Puji. 2016. Panduan Praktikum Keperawatan Maternitas. Yogyakarta:DeepublishRamadhy, Suryani, Emy \& Kh Endah Widhi Astuti. 2013. Pengaruh Pijat Oksitosin Terhadap Produksi Asi Ibu Postpartum Di BPM Wilayah Kabupaten Klaten. Jurusan Kebidanan Poltekkes Surakarta.

Walyani, Elisabeth Siwi dan Endang Purwoastuti. 2015. Asuhan Kebidanan Masa Nifas dan Menyusui. Yogyakarta: PT. Pustaka Baru. 